\title{
Lovers, enemies, and friends: The complex and coded early history of lesbian comic strip characters
}

\author{
Caitlin McGurk \\ The Ohio State University, Columbus, Ohio, USA
}

\begin{abstract}
This article seeks to recuperate four previously unexamined early newspaper comic strip characters that could lay the groundwork for queer comic studies. The titular characters in Lucy and Sophie Say Goodbye (1905), Sanjak in Terry and the Pirates (1939) by Milton Caniff, and Hank O'Hair in Brenda Starr, Reporter (1940) by Dale Messick are analyzed through close readings, supporting archival material, and interviews. The article also theorizes the identification of the creator of Lucy and Sophie Say Goodbye as George O. Frink, and offers an overview of LGBTQ comics holdings at institutions in North America.
\end{abstract}

\section{KEYWORDS}

Lesbian characters; queer comics; LGBTQ comics; Brenda Starr; Milton Caniff

When scholars examine the history of LGBTQ comics and cartoon art, focal points include Tom of Finland, underground comix, graphic novels, manga, and alternative weekly comic strips and comic books. While this list is expansive, it omits one major area: LGBTQ characters and themes in mainstream U.S. newspaper comic strips. Based on circulation numbers, ${ }^{1}$ newspaper comics have been the format most broadly consumed by a U.S. audience; therefore, LGBTQ representation in them is of utmost importance. Why have scholars relegated the investigation of LGBTQ comics and images primarily to counterculture art, where its visibility would be expected and embraced?

By the 1990s, gay male characters could be found in popular reality-based newspaper strips, including For Better Or Worse (Johnston, "Lawrence's Story") and Doonesbury (Theophano 2), the latter of which included a storyline in which the character Andy Lippincott battles AIDS. Prior to 1950, however, there were already three daily strips in the United States that had characters that could be read as lesbian: Lucy and Sophie Say Goodbye (1905), Terry and the Pirates (1934), and Brenda Starr, Reporter (1940). This article will investigate the queer content of these three comic strips, which have not received much previous scholarly attention. ${ }^{2}$ As an accessible mass medium-reaching a broad spectrum of socioeconomic classes-the most

CONTACT Caitlin McGurk mcgurk.17@osu.edu Billy Ireland Cartoon Library \& Museum, Sullivant Hall, 1813 N. High St., Columbus, OH 43210, USA.

Color versions of one or more of the figures in the article can be found online at www.tandfonline.com/wjls. 
successful newspaper comics can often be considered a bellwether for the opinions and perspectives of a wide array of people in the United States. While mainstream comic book creators and publishers have begun to include LGBTQ characters as a standard, one can tease out a genealogy of their depiction in the form by studying the treatment given to these early examples. As a result, they provide an understanding of the origins of queer representation and the progress made since. Should comics studies continue its rapid growth of the past several decades, these three comics can be seen as laying the foundation for queer comics studies within it. Accordingly, this article provides an introductory exploration of both the forgotten and the sublimated lesbian and women-loving characters in U.S. newspaper comics-those that were seen but not always understood - and a summary of institutionally held LGBTQ comics collections for further research and discovery.

\section{Lucy and Sophie Say Goodbye}

Published weekly in 1905 over the course of eight months, Lucy and Sophie Say Goodbye was written and drawn by an unidentified artist. The strip is a fascinating formal work in its innovative use of panel structure and narrative strategy, and it also seems to be the first instance of a romantic same-sex relationship in a U.S. comic strip. Amidst its brief life, its elegant and experimental drawing style, its playful yet wistfully melancholy tone, and its anonymity, there is an alchemical and alluring nature to the comic strip that demands investigation. Appearing in the first decade of U.S. newspaper comics, Lucy and Sophie Say Goodbye enjoyed the freedom and the freshness of the form. The medium was still new to U.S. readers, and artists were able to experiment with design and themes with few restrictions. Indeed, the market was thriving and thirsty for new talent, so cartoonists created multiple comic titles simultaneously, feeding the demand for material. Lucy and Sophie's plot remained consistent in each of its 33 weekly installments: two women embrace and kiss goodbye, oblivious to the complications arising around them (see Figure 1). Sometimes, the titular characters were beset by the passage of enormous amounts of time, other times by natural disaster, but all the while Lucy and Sophie remain in one another's arms, prolonging their farewell until they could meet again in the pages of the newspaper the following Sunday. Their intense embraces - unbreakable by time, nature, and human interventionmove beyond what could, on the surface, be a stereotypical gag about women taking a long time to say goodbye to their friends. Instead, these scenes transform into what can be read as a groundbreaking look at romantic love between women. Fitting, too, is the strip's placement in the cultural awareness of women who love women, as the perception of romantic friendships was just beginning to shift (Faderman, Odd Girls 18). Lucy and Sophie's relationship appears to be an example of a "Boston Marriage." The term is credited to Henry James's 1885 novel The Bostonians, which he described as "one of those friendships between women that are so common in New England" (Matthiessen and Murdock 47). Knowledge of 


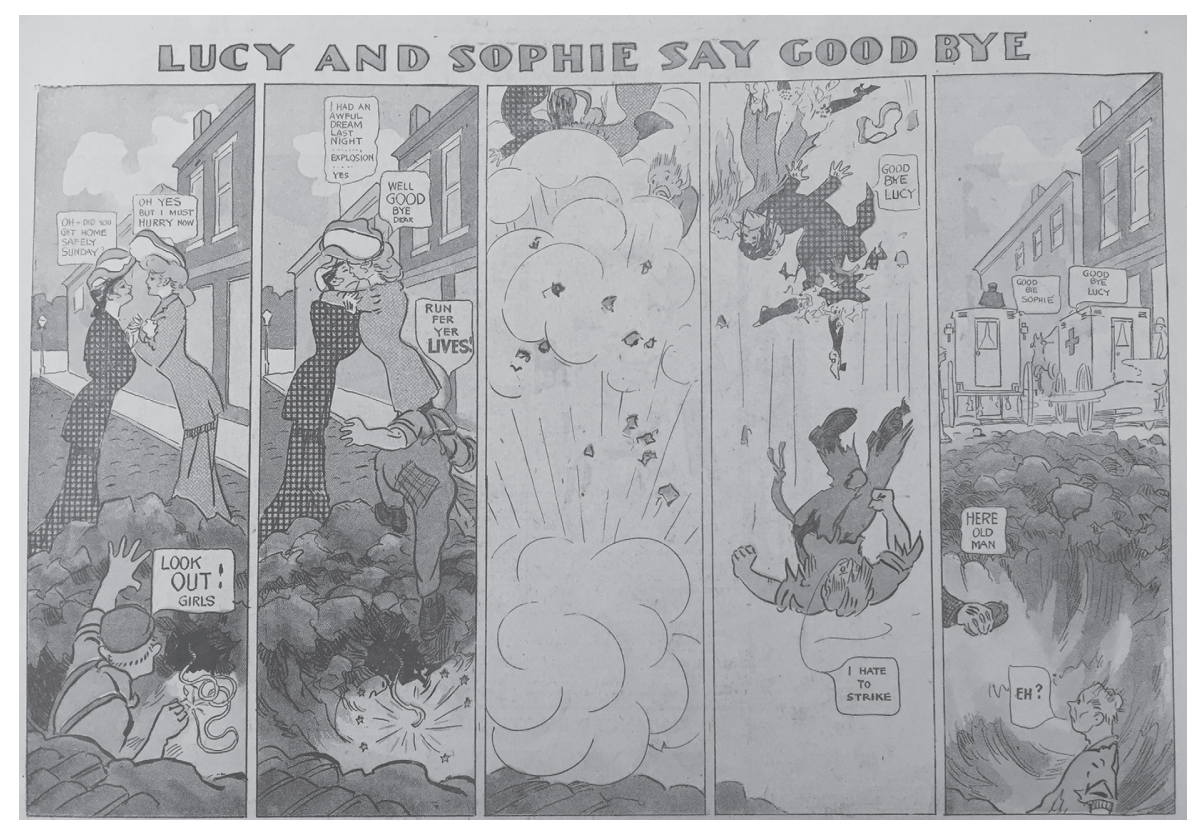

Figure 1. Lucy and Sophie Say Goodbye, May 21, 1905. Chicago Tribune.

such relationships would have been somewhat common, though not yet explicitly discussed. Of Lucy and Sophie's 33 rendezvous, those of April 16, 1905, September 10, 1905, and September 24, 1905, are the only three occurrences in which we see evidence of them having male counterparts, who make what can aptly be described as "but a shadowy appearance" (Smith-Rosenberg 53), as Lucy and Sophie downright dismiss and ignore them (which serves as the joke in the strip for that week). What would these male partners have thought about Lucy and Sophie's relationship? As Lillian Faderman has written, "for centuries men did not take [these relationships] seriously-and not only because to do so would have violated an inviolable and universal male chauvinism that mandated the notion that women had no real existence apart from men" (Faderman, "Nineteenth-Century" 32). For the husband, a wife's engagement in romantic friendship with another woman posed no real threat of abandonment, as he operated under the assumption that his wife would not be able to survive, economically, without him. These relationships were viewed as temporary, fleeting, and frivolous. While "Boston marriages" were more common between women who lived together and were in the workforce (and, therefore, not dependent on the financial support of a male partner), Lucy and Sophie instead see each other only on Sundays (apropos, as that is the only day of the week the strip was published). They occasionally acknowledge this limitation, such as on August 13, 1905, when one character says to the other: "I hope you'll be back next Sunday."

Dressed in traditional Edwardian attire and coiffure, Lucy and Sophie are likely women of decent societal standing whose Sunday meetings seem to be a joyful and fleeting highpoint of their week. The duo's farewells go beyond ordinary affection. 
Instead, they are prolonged, often holding hands or with their arms wrapped around each other's bodies, heads tilted in a passionate kiss. Tension is created in each episode by the length of time they spend saying goodbye, slowly embracing deeper and approaching a kiss, with trivial talk or repeated farewells. On August 13, 1905 (Figure 2), the artist employs a dream-like sequence in which so much time passes during the embrace that the paperboy delivering a letter to them ages from child to elderly man; meanwhile, Lucy and Sophie remain young and enraptured by each other.

Each episode is host to its own undeniable codes for Lucy and Sophie's romantic friendship. The strips are peppered with expressions of endearment for each other, such as "honey" and "dear," as well as regular flirtation and compliments. If the premise of Lucy and Sophie Say Goodbye was a simple parody of women's social behavior, certainly every strip would not necessarily need to include a passionate kiss. The element of danger or disruption that exists in each of their encounters adds to the sense of desperation for each other, as well as to their obliviousness about the chaos of the surrounding world. Bank vaults fall from the sky, elephants stampede, and tornadoes sweep through the scene. They even step into the aisle to embrace during a wedding ceremony, blocking the bride and groom-and, thus, also symbolically blocking heteronormativity - while they simultaneously mirror the positions of the soon-to-be wedded couple. Onlookers exclaim their disapproval: "The idea!," "For mercy sakes!," and so on. The romantic nature of their relationship is confirmed in the final appearance of Lucy and Sophie Say Goodbye on October 15, 1905: the characters are spied by two patrol men who, commenting on their affectionate behavior, call them "nutty" and "two crazy ones," and proceed

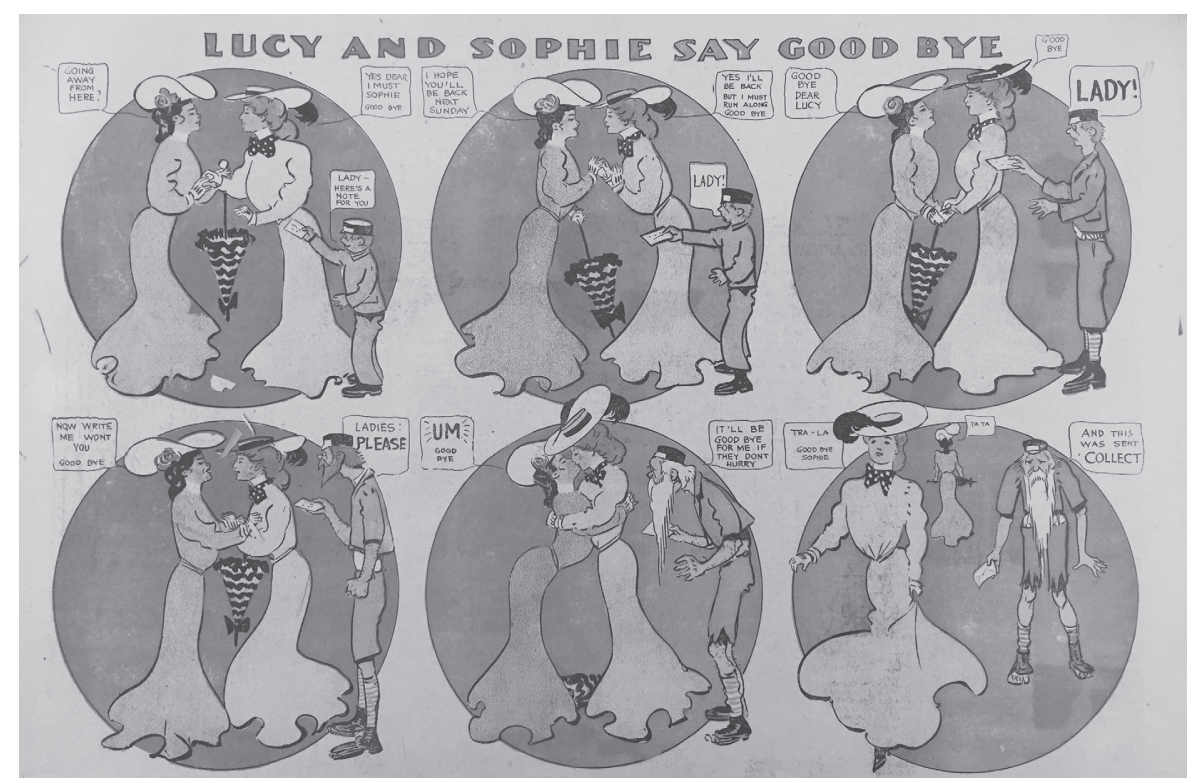

Figure 2. Lucy and Sophie Say Goodbye, August 13, 1905. Chicago Tribune. 


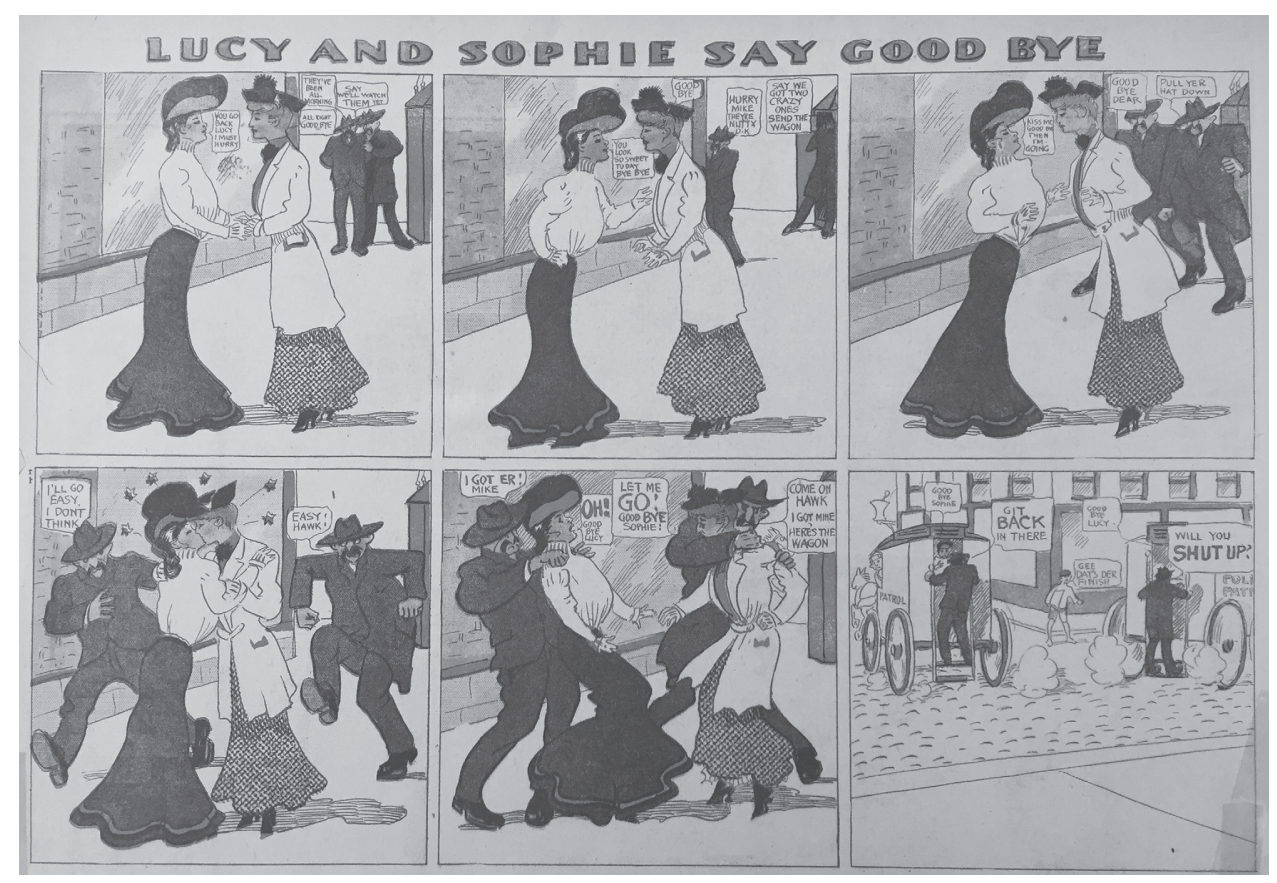

Figure 3. Lucy and Sophie Say Goodbye, October 15, 1905. Chicago Tribune.

to apprehend them-forcing them into paddy wagons to be arrested or committed to a mental institution (Figure 3). This final criminalization of the women's relationship, on top of the continued disapproval, comments, and chaos surrounding them in the series, asserts the sociohistorical objection and repression of this type of love relationship.

It seems particularly strange that the artist intentionally chose to remain anonymous, especially given the exposure that the then-successful medium would provide for an artist at the time, as well as the common practice of crediting work. However, the artist may have concealed his or her identity to avoid complaint and controversy over interpretation of Lucy and Sophie as romantic friends or lovers.

After conducting close readings of the comic strip and comparing it to others that appeared at the time, I believe with reasonable confidence that the creator is cartoonist George O. Frink. Frink is known best as the original creator of the longrunning comic strip Slim Jim and the Force (1910), which was derived from his earlier strip Circus Solly (1904). Frink was exceptionally prolific during his career at the Chicago Tribune. According to comic historian Allan Holtz (2011), "Frink was a restless soul; he did several dozen different series during his tenure." In the year 1905 alone, Frink created short-lived titles including Tommy Town, Ratty and Algy, Mister Makinbrake, The Goat Family, and likely others. When compared in particular to Frink's Ratty \& Algy and Mister Makinbrake, it seems likely that Lucy and Sophie Say Goodbye was created by the same hand (see Figure 4)-most notably in the lettering style and design of the female characters. 


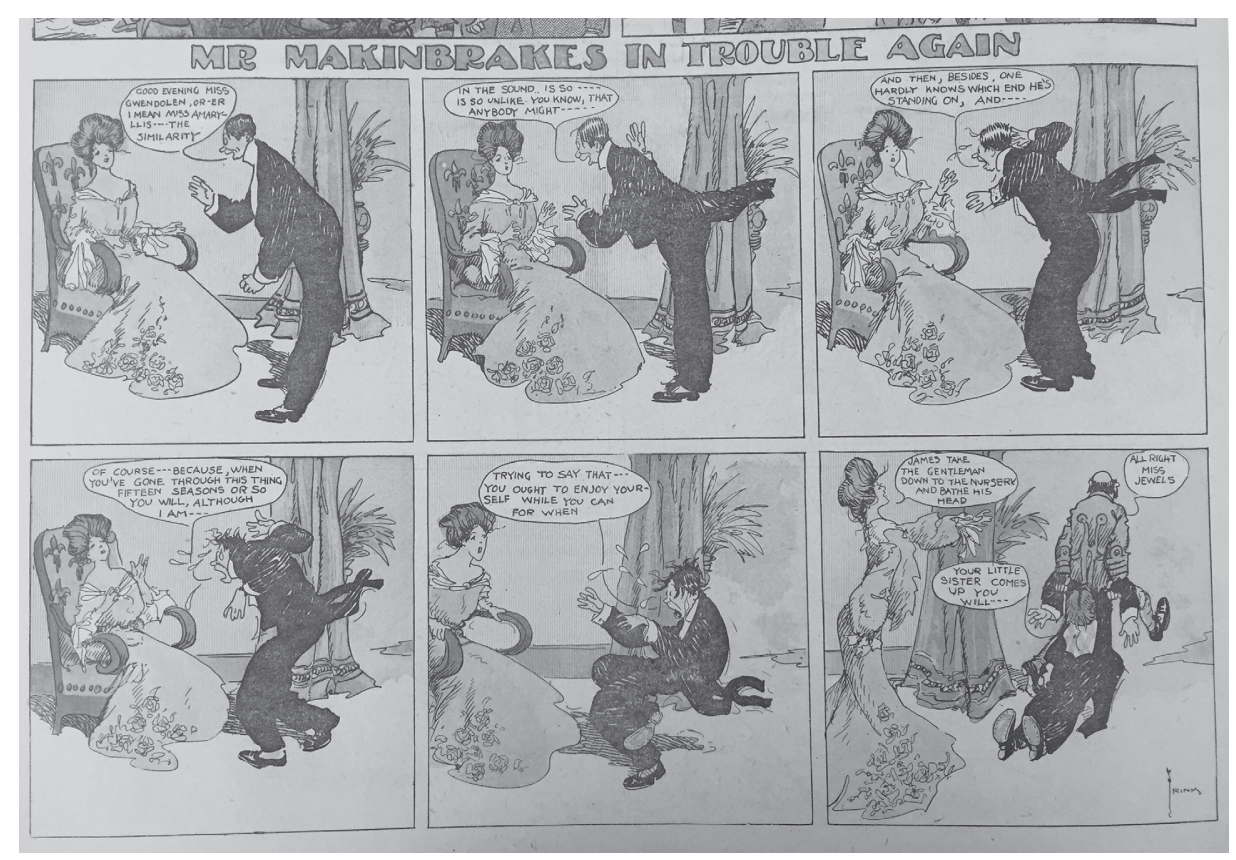

Figure 4. Mr. Makinbrake by George O. Frink. April 2, 1905. Chicago Tribune.

In each of his comics, Frink's style varied as he experimented with his skills, modified to fit the subject matter and tone of the comic's theme. His occasional use of surrealism (particularly in Lucy and Sophie Say Goodbye) was undoubtedly inspired by Winsor McCay, whose work also appeared in the Chicago Tribune at the time. Unfortunately, very little is definitively known about Frink's life. According to census reports mined by comics blogger Alex Jay, Frink was born in Indiana in either 1872 or 1874, married and divorced by 1900, and appears to have stayed single for the remainder of his life. He was the head of his household in his early twenties in Indianapolis, and remained the head when he relocated to Chicago, Illinois, between 1900-1910 with his mother, sister-in-law, and niece. Despite his natural gift for cartooning and his success, Frink's career ended abruptly and mysteriously by 1912. He was later listed in the U.S. Federal Census to have been institutionalized in the Elgin State Hospital mental health facility; he died there in 1932 (Jay).

Much like the vague details of his life, Frink's possible role in creating Lucy and Sophie Say Goodbye, and why, remains unconfirmed. How the reading public of the day interpreted Lucy and Sophie's relationship is likewise unknown and, unfortunately, the comic's underdeveloped plot structure and short lifespan leave it frustratingly open for interpretation. Of course, it could be hypothesized that Frink either knew women in relationships like Lucy and Sophie's, or perhaps questioned his own sexuality or gender identity. Living and working in a large and diverse city like Chicago would provide Frink with exposure to more unconventional experiences at the turn of the century, which would align with the emerging social 
awareness and condemnation of love relationships between women. Frink also resided exclusively with female relatives for the majority of his life, and his only marriage was very short-lived. That said, it is difficult to ignore the parallel of the Lucy and Sophie Say Goodbye ending, with the two characters being arrested or committed to an asylum in the final strip, and Frink's life ending in a mental institution. As concern arose over same-sex relationships in the United States, ultimately leading to the criminalization of and discrimination against homosexuals, if Frink were the creator of Lucy and Sophie Say Goodbye and in any way queer himself, he would likely suspect that his characters would have to say their final farewell in the same way he gave his: ostracized and institutionalized.

\section{Terry and the Pirates and Sanjak}

Of the four characters studied in this article, the one most commonly identified as an early lesbian character is Milton Caniff s evil French master of disguise: Sanjak. In Robert C. Harvey's biography of Milton Caniff, Meanwhile, he refers to Sanjak as "a master villainess who hypnotizes and kidnaps the girl with criminal designs that veil lesbian intentions" (309), as seen in Figure 5. Caniff asserted that he named Sanjak after a tiny island near Lesbos in the Agean Sea but that "nobody ever caught on" to that connection (Dorf 231). Although there is no island by this name, the meaning of the word itself may reveal other truths. During the Ottoman Empire, a "sanjak" referred to administrative divisions of territory; there was, indeed, a sanjak of Lesbos at the time. Further, the word "sanjak" is derived from the Turkish word "sancak," which means "flag" (Imber 178). A flag, a warning, a tip-and something divided. Caniff said, "I made the point with the people who could get the point that this was a lesbian character... But she never did anything overt: you had to read it in. And enough people got it to write in and say, 'Ah, ha! I understand" (qtd in Harvey 309). Caniff was a master of storytelling and character development, so the deliberate naming of this character is fitting. Readers were first introduced to the character on

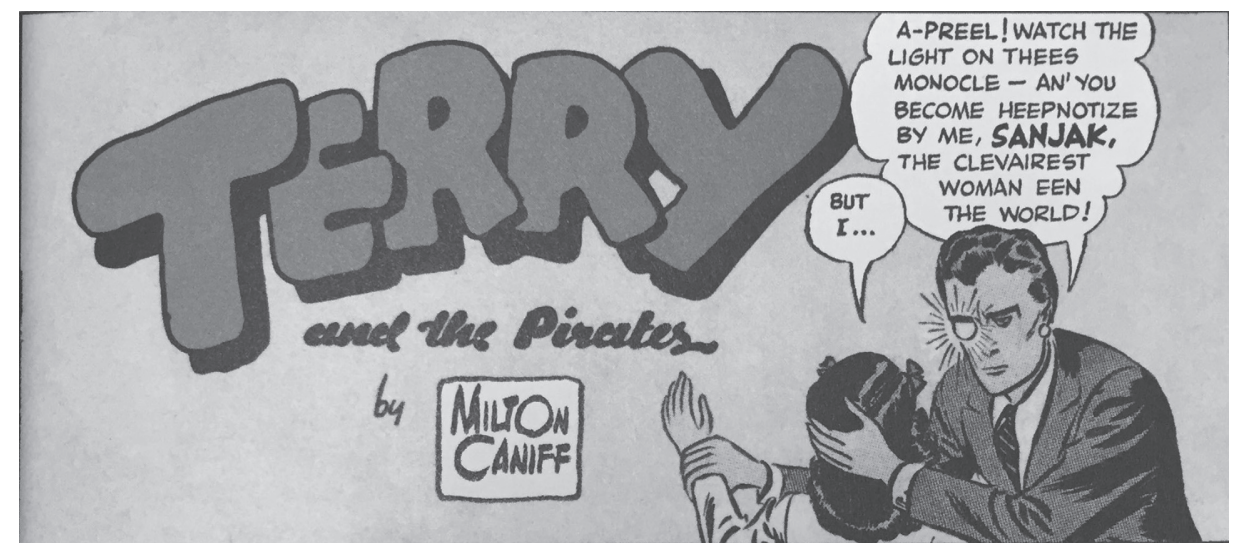

Figure 5. Terry and the Pirates by Milton Caniff. February 19, 1939. 


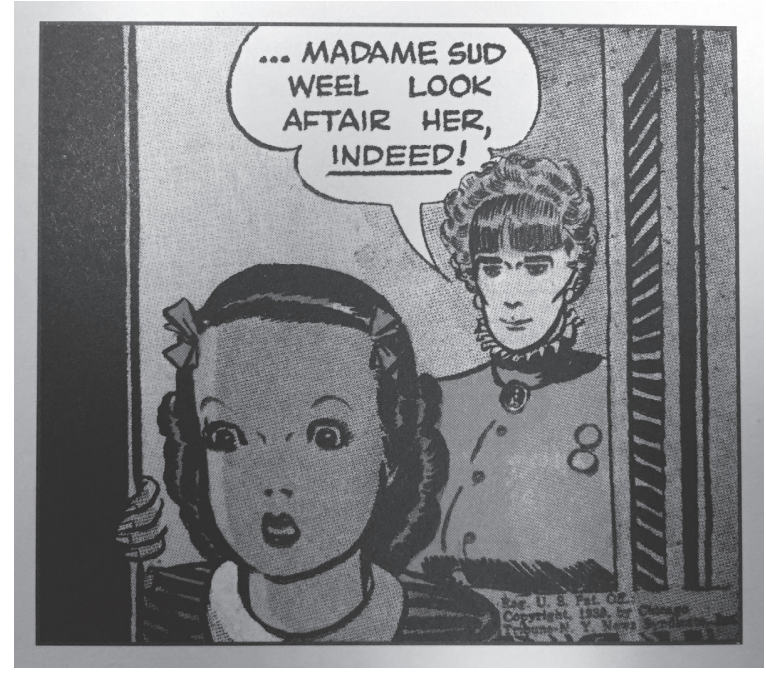

Figure 6. Terry and the Pirates by Milton Caniff, February 5, 1939.

January 1, 1939, as Madame Sud-Sanjak's stout, matronly, and seemingly harmless alter ego. (Figure 6). She is the owner of "Hotel Sud," where April Kane (who also makes her debut in this storyline) is staying, as well as the leading characters Terry and Pat Ryan, who are investigating the disappearance of April's brother, Dillon. April is sweet, delicate, and naïve, and instantly becomes the love interest of Terry.

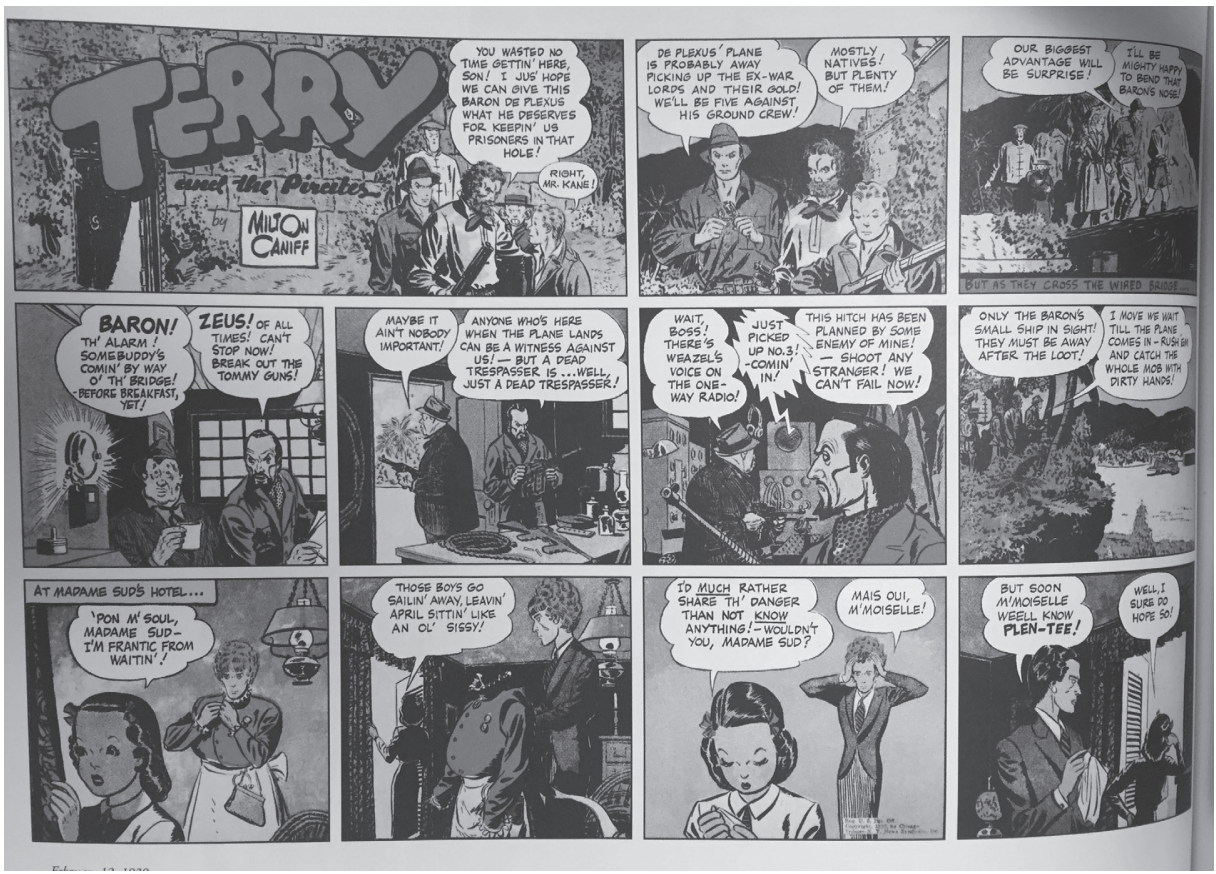

Figure 7. Terry and the Pirates by Milton Caniff, February 12, 1939. 
As the drama unfolds, Terry and Pat Ryan leave the hotel on a mission to find Dillon, and readers learn that the trustworthy and accommodating Madame Sud is not who she appears to be. On February 12, 1939, in a shocking reveal, Madame Sud removes her feminine facade (merely a costume "built on a frame") and reveals her monstrous identity: Sanjak, a woman dressed in men's clothing, wearing a monocle, and carrying a handkerchief (Figure 7). Caniff infused Sanjak with so many elements of the stereotype of the "mannish lesbian" that he never needed any of the characters to directly come out and say it. Though Sanjak could be viewed through the lens of transvestism, her interactions with her captive, April, repeatedly indicate her romantic desire. Sanjak consistently refers to April in terms of endearment, including "chéri," "darling," and "baby." Additionally, Sanjak consistently strives to impress April: she shows off her secret hideaway and brags of her own power and brilliance. Furthermore, the villainess touches April often, holding her at the waist, hand, or shoulder, or tenderly cupping her chin (Figures 8 and 9). As a result, readers do not get the sense that Sanjak wants to kill April (who is, after all, a hostage that she has unwillingly kidnapped). Instead, Sanjak seems far more interested in wooing and possessing the young girl.

This situation arguably reaches its apex when Sanjak hypnotizes April. She commands the girl to obey and, during this process, mimics a seductive posture and embrace one would take before a kiss. This idea feeds directly into the then-common misconception of lesbians as villains and predators of the innocent: they were "congenital inverts," born criminals, moral deviants, and freaks due to bad heredity (Faderman, Odd Girls 40). It is also worth noting that the comic strip's main character, Terry, is falling in love with April at this same time, and Caniff seems to have purposefully positioned Terry and Sanjak in competition for the young girl's affections.

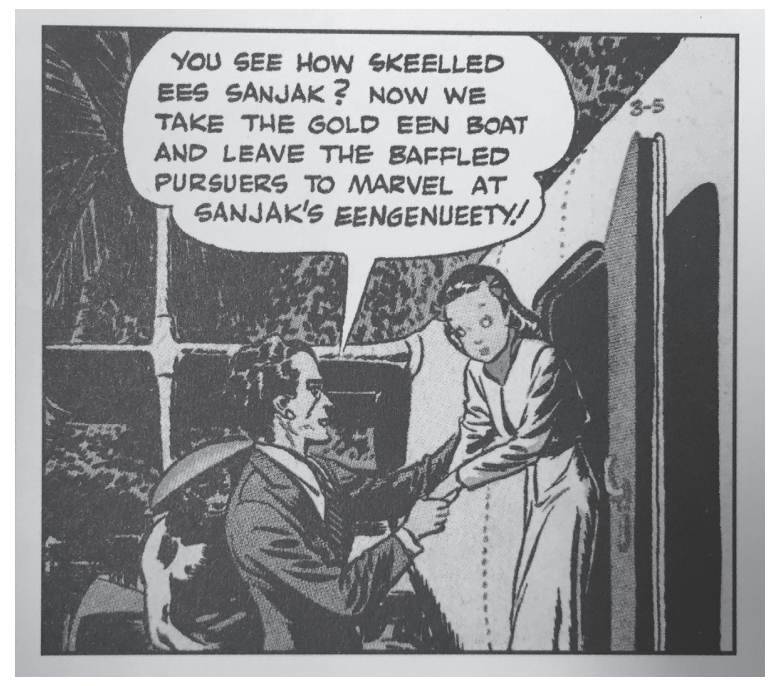

Figure 8. Terry and the Pirates by Milton Caniff, March 5, 1939. 


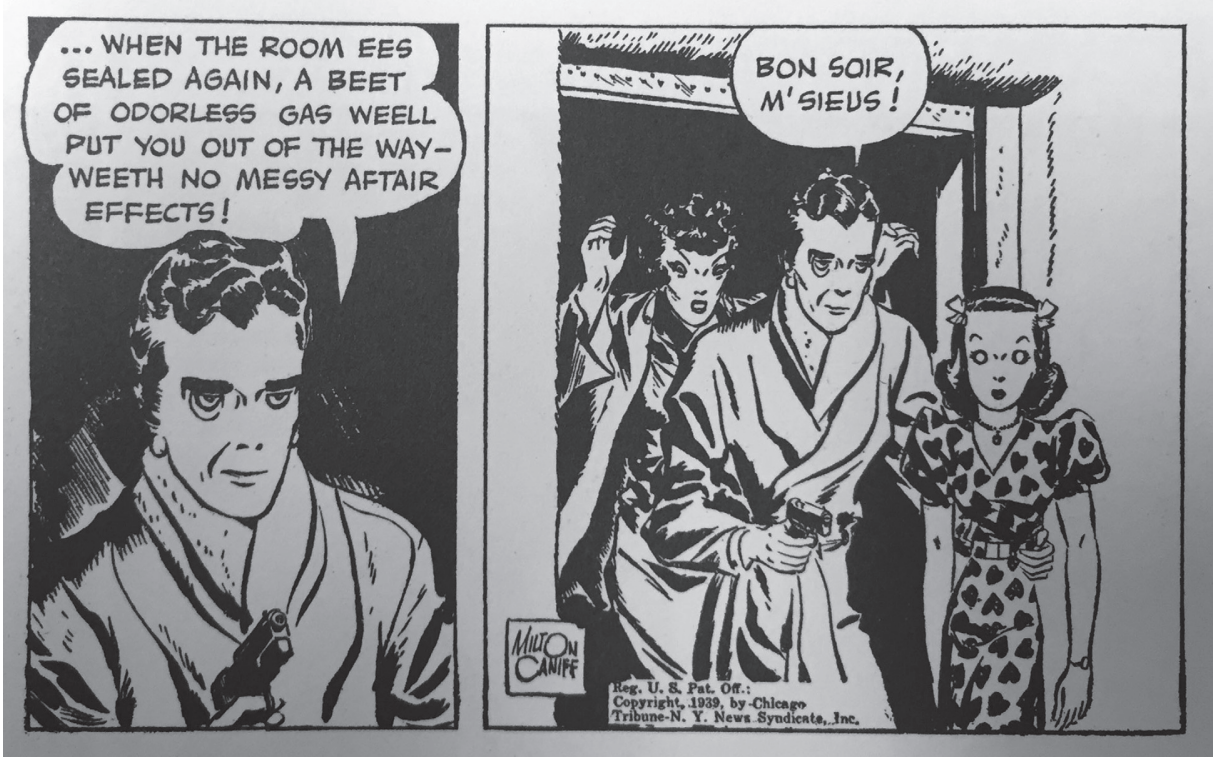

Figure 9. Terry and the Pirates by Milton Caniff, April 6, 1939.

Caniff s archive of personal correspondence, held by The Ohio State University's Billy Ireland Cartoon Library \& Museum, reveals a more positive interpretation of Sanjak. While hardly any readers wrote in to criticize Caniff for including what would be considered a taboo character for the time, a number of fans wrote to praise him for it: expressing their love of the character, and encouraging him to keep her around and on the side of good. A handwritten note in the Milton Caniff Collection from April 1939 and signed by "Lucille D.” from New York bravely provides a word of advice for April Kane:

Dear Voice Of The People, While reading the newspaper I became very interested in a comic section in the news. You know Terry and the Pirates. So it would please me very much if you would print this letter in the paper. I dare you to print it. I will look for it in the paper next week [:] "Dear April, If I were you I would go for Sanjak and forget Terry. You know Sanjak is fine. I wish she was a real person, I could go for her myself."

Additionally, a typewritten letter dated February 1939-the month of Sanjak's debut-from a reader whose gender identity is masked by their simple signature of "THR" has the following message for the cartoonist:

I want to congratulate you on your excellent characterization of Sanjak. She has a subtle enjoyable cynicism to her, and yet for all of her cynicism, there is certainly a note of loneliness and even sadness in her. Perhaps I am carrying my interpretation too far, but for Pete's sake, don't spoil a good intention by making her pure villain, and even if she be a villain, she is too enjoyable to be deprecated for it. Your study of her is a revelation after the usual goo of pure villainy that one finds in the usual cartoon strip. She's a jewel. Let her stay single, unafraid, and cynically humorous as ever when she fades out of your strip. The above request may seem unusual, Mr. Caniff, but believe me, I've enjoyed Sanjak too 
much not to put in a good word for her, whereas I have a faint suspicion others may not entertain the same toleration or liking for her that I do.

Caniffs Sanjak was indeed a revelation to some readers, but the overall minimal response to her character-only a small handful set against thousands of letters received over the course of his career-also indicates the public's naïvete about her as a lesbian. While the inclusion of a character such as Sanjak in a major U.S. comic strip in the 1930s may seem innovative, Caniff's reliance on negative stereotypes of the time prevents it from being a progressive step toward lesbian visibility.

\section{Brenda Starr's Hank O'Hair}

In a 2013 interview with Jennifer Camper, the Lambda Literary Award winning cartoonist was asked, "What are the first lesbians you saw in comics?" Camper offered the following response:

Brenda [Starr]'s newsroom pal, Hank, usually dressed in men's clothing and was very butch. Hank wasn't explicitly lesbian, and I think she even had a husband at one point. She was written as a plain woman, not glamorous like Brenda, and she was tough, practical and good at her job. Her name, character, appearance and actions were all consistent with her being a swaggering dyke. I discovered her when I was young and was fascinated by her. (qtd in Cohen 2013)

Brenda Starr, Reporter is one of the most successful comic strips created by a woman. Dale Messick, born Dalia, used the pseudonym Dale to conceal her gender in the male-dominated field of cartooning when she began submitting comics for publication in the late 1930s (Robbins and Yronwode 40). Brenda Starr, Reporter debuted on June 30,1940, as a Sunday comic feature and by 1944 was also running as a daily strip. At its peak, Brenda Starr reached a worldwide daily readership of more than 60 million (Reynolds 100). A household name and fashion icon thanks to Messick's eye for design and passion for hats and paper dolls, Brenda was a redheaded bombshell journalist for the big city newspaper The Flash.

In the same way that Dale Messick was a female cartoonist working in a maledominated field, Brenda Starr was a female journalist working in an equally maledominated profession. Perhaps not surprisingly, Messick's creation repeatedly subverted the norms, standards, and conventions of its time; the comic was riddled

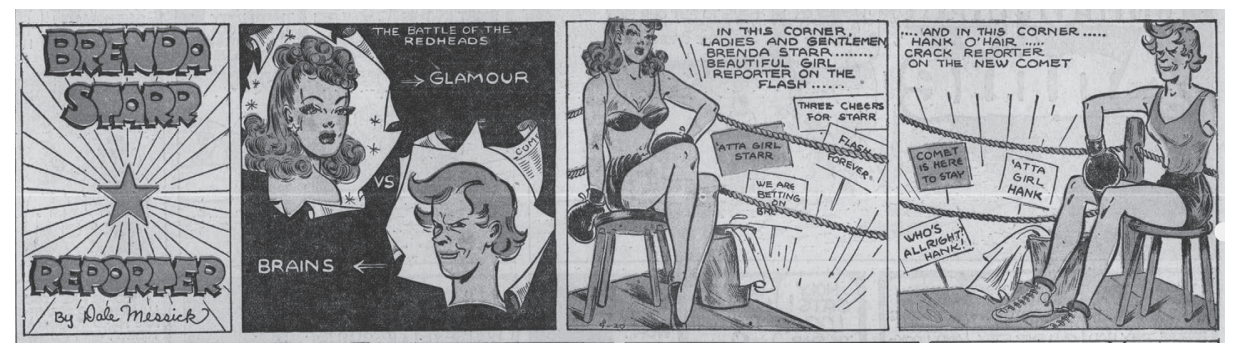

Figure 10. Brenda Starr, Reporter by Dale Messick. September 19, 1942. 


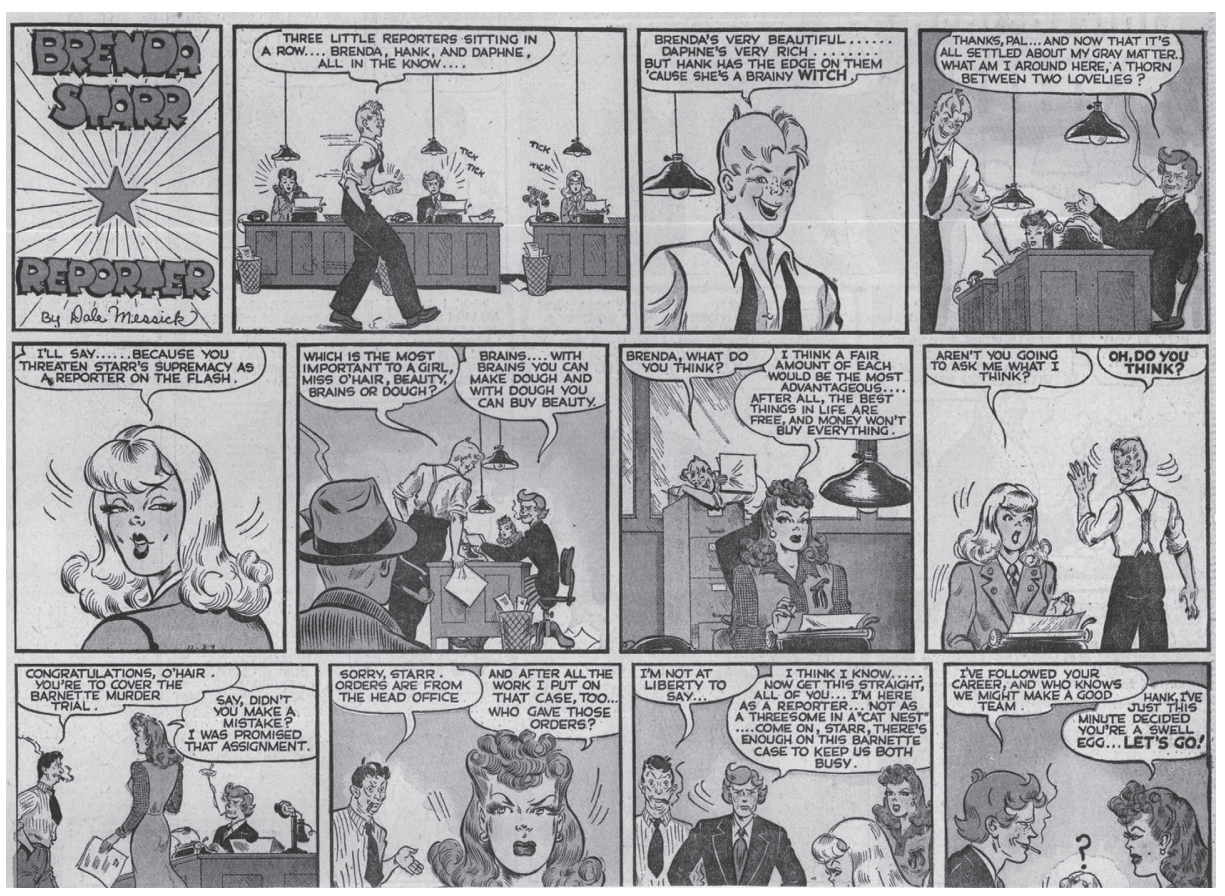

Figure 11. Brenda Starr, Reporter by Dale Messick. November 28, 1942.

with hidden identities and challenges to the status quo. At the beginning of her time on staff, Brenda's main colleagues reflected the stereotypical journalism crew: the cigar-chomping managing editor of the paper, Atwell Livwright, and Pesky Miller, the boy reporter whose first name captures his essence. In 1942, a "rough, tough, mannish creature in broken-down tweed suits and flat heels" is introduced into Brenda's world and ours: Hank O'Hair.

After Hank is hired at The Flash, she quickly becomes friends with Brenda. Functioning as complimentary inverses of each other (demonstrated in Figure 10), Brenda's red hair flows and pops off the page, while Hank's locks are unflatteringly cropped behind the ears and often tucked underneath her signature black beret. Rarely seen without a cigarette dangling from her lip (Figure 11), "the homely Hank O'Hair” (Reynolds 101) primarily wears men's clothing, lounges with her legs up on the office table and her hands crossed behind her head, and "helps keep our gal's feet on the pavement." Almost always present but rarely constituting the center of attention, Hank provides commentary and advice about Brenda's exploits. In a Chicago Sunday Tribune article about the strip from January 14, 1945, “A Star Reporter Writes about a Starr, Reporter,” Marcia Winn subtly comments, "Naturally, Hank is a threat only in reporting" (Winn 1). Having changed her own first name to one that is commonly coded as male, Messick, in an instance of art imitating life, also blurred her character's gender identity by giving Hank a typically masculine name. It is possible that Messick derived the unique name 
"Hank O’Hair" from the Rudyard Kipling poem “The Vampire," whose first verse reads:
A fool there was and he made his prayer
(Even as you and I!)
To a rag and a bone and a hank of hair
(We called her the woman who did not care)
But the fool he called her his lady fair-
(Even as you and I!) (Kipling 196)

In the poem, Kipling reduces women to merely clothes, bones, and hair-in contrast to the divine, rose-colored view that a man can project onto a love interest. The poem laments men who pine for women who disregard their advances; women who do not notice, reciprocate, or perhaps love men at all. If Messick did derive the name from Kipling's poem, it also reinforces the physical contrast between Brenda's flashy and manicured red hair and Hank's more callous and unfeminine cut.

While Messick never directly stated that Hank was intended to be a lesbian, the comments by Jennifer Camper affirm that at least some readers did see her in this way. The strength and importance of this character lie in the fact that LGBTQ readers were able to see themselves reflected and, thus, represented-however imperfectly, and potentially inadequately-in Hank. Messick claimed that she got her ideas "from real people, real experiences, real things that happen to me" (Reynolds 101), reinforcing to readers that women who are like Hank, and like themselves, were really out there.

On March 22, 2017, I conducted a phone interview with Dale Messick's daughter, Starr Rohrman. I asked her about Hank's vague identity and her

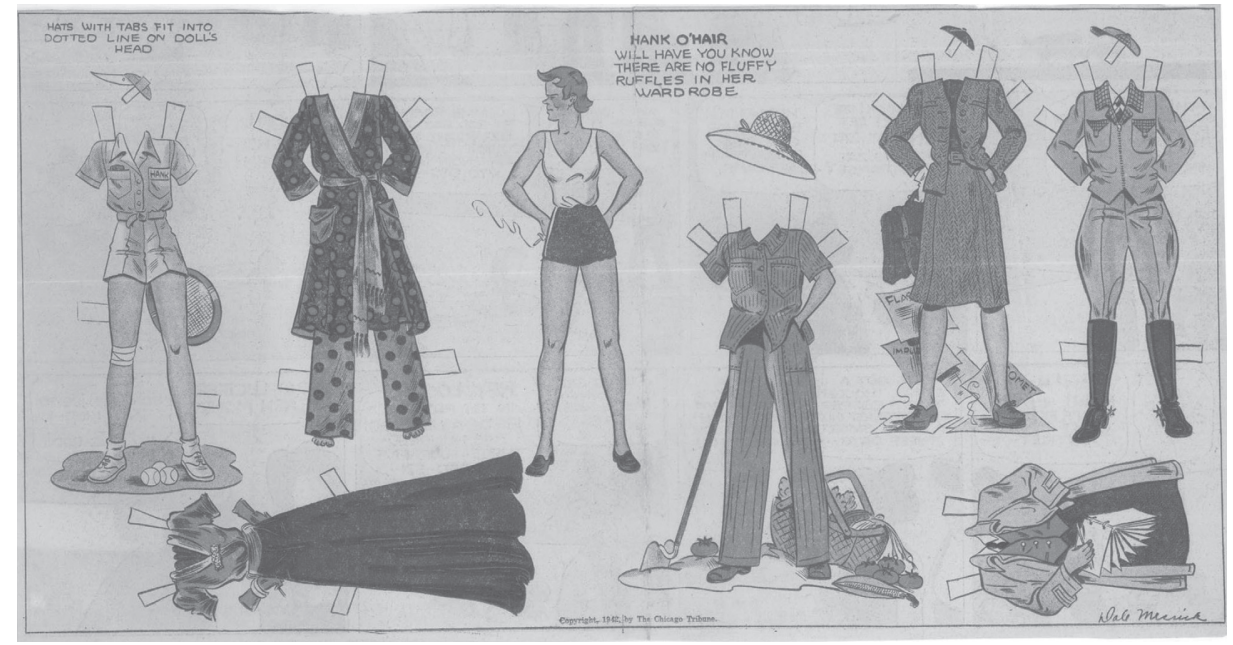

Figure 12. Brenda Starr, Reporter paper doll of Hank O'Hair by Dale Messick, August 30, 1942. 
mother's possible intention with the character. "Well, people didn't come out in those days," she told me, continuing:

And you know my mother traditionally had many, many gay friends, of both genders. Most artistic people did and I never thought very much about it [....] Looking back in our family... there was an aunt who very obviously was gay and we all knew and we accepted her totally, but nobody ever talked about it. We all accepted it, we just didn't discuss it. (Rohrman)

At least three paper doll series were published featuring Hank, each of which offer a glimpse of her androgynous style that further coded her as queer in comparison to the stereotypical female of the 1940s (see Figure 12).

In the Chicago Tribune article "Dale Messick: Her Starr Sparkles with Glamour" by Peter Gorner, from March 13, 1974, the cartoonist comments about Hank O'Hair: “I took [her] after a girl reporter [that] I knew in New York, rather a masculine gal. But I got hundreds of letters saying people thought Hank was a lesbian and to keep her away from Brenda. I finally had to get her married and have a baby" (Gorner 6). During our phone call, Starr Messick confirmed that, lamentably, those "hundreds of letters" were lost due to her mother's proclivity for throwing things away. Of course, this event is unfortunate, as these items would help to indicate how the character was publicly received, at least by some readers of the strip.

The cartoonist's anecdote about Hank makes clear that she aligned the life of this character with a heterosexual, conservative storyline due to the pressure that she received from readers who feared the possibility of Hank being a lesbian. Of course, it is possible that she also received editorial pressure to do so. Getting married and having a baby were not inherently of interest to Hank, but Messick "had to" have her do it. Speaking to this pressure, Starr Rohrman explained,

When I was growing up I remember [my mother] had Brenda smoke a cigar, and she was banned in Boston. It was just outrageous, it was horrible. The things that people react to over the years.... Cleavage and all that sort of thing, it was just verboten, it was not done.... She has to probably be a gay character, I guess that's why she married her off [due to controversy]. (Rohrman)

Unfortunately, the changes in Hank's lifestyle seemed just as forced to readers then as they appear to critics today: over the course of a few weeks' worth of strips in 1946, major changes occur when a stunning male staff artist, Pierre Palette, is hired at The Flash. Palette's arrival impacts everyone in the newsroom, except for Hank. He is a heartthrob-every woman he meets falls in love with him; even Brenda is enamored. Pierre is so attractive that, within just a few weeks of his debut, he laments not being able to get anything done due to the swooning women stalking his every move. Jokingly, Hank suggests that Pierre get a bodyguard, and to her surprise and insult, he asks her to take on the job. Even more astoundingly, she agrees. The strips that follow reveal a new side of Hank: her rough exterior falls away and an inner monologue reveals that she has an insecure and even self- 


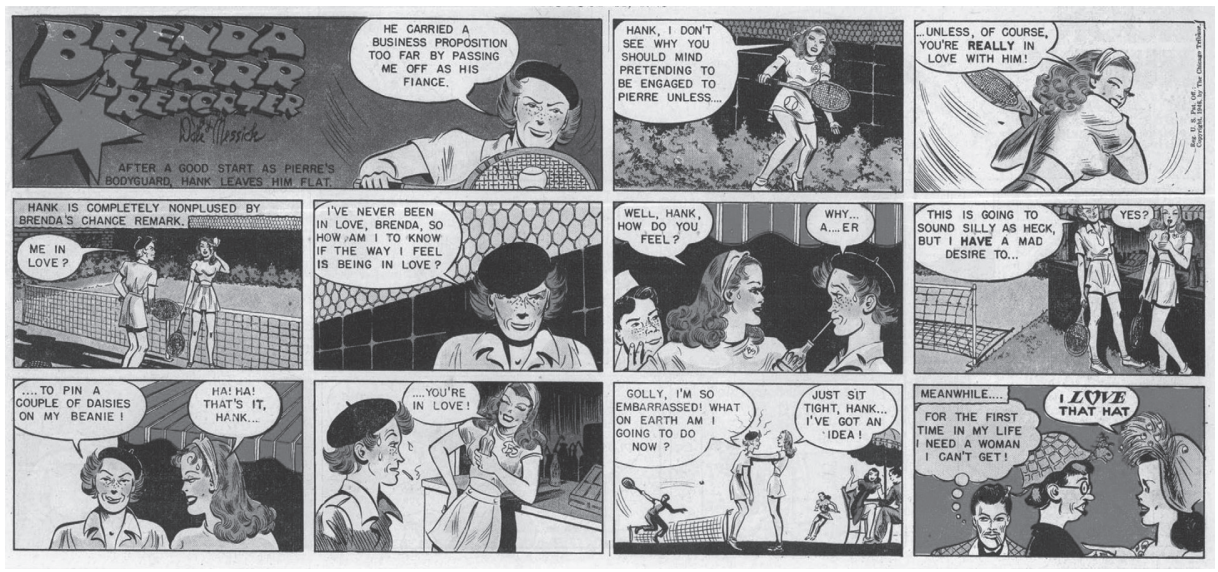

Figure 13. Brenda Starr, Reporter by Dale Messick. August 11, 1946.

loathing side. For example, Hank comments that Pierre must want her around because she is hideous enough to "scare the rats out of his basement." Suddenly, Hank's eyes seem to soften, and her previously unnoticeable eyelashes even appear to have lengthened as a result of Pierre's presence. As their bizarre bodyguard arrangement develops, Pierre begins referring to Hank as his fiancée to ward off the hordes of persistent women. Moreover, as romantic tension builds between O'Hair and Palette, they soon decide to make their sham relationship a reality. The Sunday strip shown in Figure 13 was likely read with pangs of sadness by at least some Hank fans, as we see Brenda press her about her true feelings for Pierre. The formerly tough and tight-lipped Hank admits to a sudden urge to pin flowers to her hat when she thinks of him. Messick completes this plotline on December 23, 1946, when Pierre and Hank wed. Perhaps the one consolation for fans was that Hank insists on a tweed suit for the ceremony rather than the more conventional dress that Brenda was pushing her to wear.

Messick was no stranger to controversy throughout her career, from the aforementioned cigar smoking scandal to push-back for drawing a belly button on Brenda until the 1970s. The need for readership approval leads characters to restrained, repressed lives. Even Brenda succumbed to such a fate. In the words of Messick: "This is the same reason I can't marry her off. She has to stay so darn good, sexy but untouchable, the All-American girl. Oh, she has lots of adventures and romances, but when it gets down to the nitty-gritty, she's a virgin" (Gorner 6). Despite the wing-clipping of these characters, Messick's Hank O'Hair left her mark on readers-like future cartoonist Jennifer Camper-who needed her.

\section{Conclusion and areas for further research}

While this essay serves as a primer for the study of LGBTQ characters, specifically early lesbian representation in mainstream U.S. comic strips, it is in no way exhaustive. There are many other examples of queer characters who have made 
cameos in comic strips throughout history, including another from Milton Caniffs Terry and the Pirates: Papa Pyzon (Heer 2009). One of the likely reasons for the lack of research in this area, however, and on comic strips in particular, is the limited availability of reprint books and incomplete digitization of historic newspaper comic sections. The potential for scholarly study of comics is growing rapidly as these previously low-priority collections find homes in major research institutions across the United States. While The Ohio State University Billy Ireland Cartoon Library \& Museum (BICLM) has the largest collection of comics materials in the world, more institutions are beginning to pay attention to the medium. The BICLM collection has informed this article immensely, as it holds the Milton Caniff Collection as well as a nearly complete run of Lucy and Sophie Say Goodbye and Brenda Starr, Reporter newspaper clippings. These clippings form part of the San Francisco Academy of Comic Art Collection, which contains 350,000 original Sunday comic strip clippings and 2.5 million dailies-an incomparable resource for mining the largely unexamined histories of U.S. comic strips (Robb 7). While many contemporary LGBTQ cartoonists' collections, including Alison Bechdel's and Ellen Forney's, have not yet been physically placed with an institution, BICLM houses the collections of transgender cartoonists Katherine Collins and Edie Fake, and Columbia University became home to the archives of Howard Cruse (Gay Comix, Stuck Rubber Baby) in 2016. Paige Braddock, creator of long-running comic strip Jane's World, has placed her collection with her alma mater, University of Tennessee. The Leslie-Lohman Museum of Gay and Lesbian Art in New York City holds many cartoon and comic resources, including work from Neel Bate and G. B. Jones. If the overdue critical attention to comics continues to grow over the next few decades, more institutions in the United States will hopefully see an influx of collections from pioneering LGBTQ cartoonists.

If comics are the "bastard offspring of art and commerce" (Spiegelman 1990), then early LGBTQ comic strip characters and creators can be regarded as the neglected orphans within it. While the release of recent collections like The Complete Wimmen's Comix (Robbins) and No Straight Lines: Four Decades of Queer Comics (Hall) have given much-needed attention to titles, artists, and figures from the late 1960s to the present day, those who appeared in prior decades remain relatively unexamined. It has taken nearly 100 years for the comics medium to be packaged into the palatable format of the graphic novel, which receives by far the most scholarly attention, putting strips_comics' first format-on the far other end of that spectrum. The breadth of comic strip titles that fall between and beyond the obscure and forgotten Lucy and Sophie Say Goodbye and the extremely popular Terry and the Pirates and Brenda Starr, Reporter is immense. What else could scholars be missing? There are undoubtedly more overlooked characters that have been ignored for too long and could aid in creating a more robust lineage of queer female comics history. While many of the LGBTQ characters in early newspaper comics echoed the negative stereotypes of their time, there may be others like 
Hank O'Hair who were allowed, if only temporarily, to have the autonomy to represent other forms of women's possible gender and sexual identities.

\section{Notes}

1. In the year 1940, the average Sunday newspaper circulation reached 32,371,000 based on data published by the Pew Research Center (http://www.journalism.org/fact-sheet/newspa pers/). By comparison, the average monthly circulation of comic books in 1940 was 17,000,000 according to Matthew Guillen's book Reading America: Text as a Cultural Force (2007, p. 335).

2. One of the few exceptions to this situation is Michelle Ann Abate's (2018) article, "You Are Een the House of Sanjak!': Terry and the Pirates, the First Lesbian Character in U.S. Comics, and the Roots of Wonder Woman.”.

\section{Notes on contributor}

Caitlin McGurk is an assistant professor at The Ohio State University and the associate curator of outreach for the Billy Ireland Cartoon Museum and Library at OSU.

\section{References}

Abate, Michelle Ann. "You Are Een the House of Sanjak!': Terry and the Pirates, the First Lesbian Character in U.S. Comics, and the Roots of Wonder Woman." ImageTexT, vol. 9, no. 3, pp 2018.

Cohen, Paige. "Lambda Literary Comic Book Week: Graphic Artists and Novelists on the Comic Books They Love." Lambda Literary, 15 July 2013. https://www.lambdaliterary.org/features/07/ 07/lambda-literary-comic-book-week-graphic-artists-and-novelists-on-the-comic-books-theylove/. Accessed 10 April 2017.

Dorf, Shel. "Shel Dorf Interviews Milton Caniff." Milton Caniff: Conversations, edited by Robert C. Harvey. University Press of Mississippi, 2002, pp. 88-108.

Faderman, Lillian. "Nineteenth-Century Boston Marriage as a Possible Lesson for Today." Boston Marriages: Romantic but Asexual Relationships among Contemporary Lesbians, edited by Esther D. Rothblum and Kathleen A. Brehony. University of Massachusetts Press, 1993, pp. 29-42.

Faderman, Lillian. Odd Girls and Twilight Lovers: A History of Lesbian Life in Twentieth-Century America. Columbia University Press, 2012.

Gorner, Peter. "Dale Messick: Her Starr Sparkles with Glamour." Chicago Tribune, 13 March 1974, p. 6.

Guillen, Matthew. Reading America: Text as a Cultural Force. Academica Press, 2007.

Hall, Justin, editor. No Straight Lines: Four Decades of Queer Comics. Fantagraphics, 2012.

Harvey, Robert C. Meanwhile... A Biography of Milton Caniff, Creator of Terry and the Pirates and Steve Canyon. Fantagraphics, 2007.

Heer, Jeet. "Mickey Mouse, Homophobe.” Sans Everything, 16 December 2009. https://sansevery thing.wordpress.com/2009/12/16/mickey-mouse-homophobe/. Accessed 2 October 2017.

Holtz, Allan. "Obscurity of the Day: Ambitious Activity the Amateur Detective." Stripper's Guide, 5 July 2011. https://strippersguide.blogspot.com/2011/07/obscurity-of-day-ambi tious-activity.html. Accessed 21 February 2017.

Imber, Colin. The Ottoman Empire, 1300-1650: The Structure of Power. Palgrave Macmillan, 2010. 
Jay, Alex. “Ink-Slingers Profile: George O. Frink.” Stripper's Guide, 6 December 2012, https:// strippersguide.blogspot.com/2012/11/ink-singer-profiles-george-o-frink.html. Accessed 8 February 2017.

Johnston, Lynn. "Lawrence's Story." Lawrence Poirier: The First Gay Character in a Syndicated Comic Strip Comes Out. https://www.fborfw.com/features/lawrence/index.php?page=five. Accessed 21 February 2017.

Kipling, Rudyard. “The Vampire.” Kipling's Poems, edited by Wallace Rice. George M. Hill Company, 1899, pp. 196.

Matthiessen, F. O., and Kenneth B. Murdock, editors. The Notebooks of Henry James. Oxford University Press, 1981.

Reynolds, Moira Davison. Comic Strip Artists in American Newspapers, 1945-1980. McFarland \& Co., 2003.

Robb, Jenny E. "Bill Blackbeard: The Collector Who Rescued the Comics." Journal of American Culture, vol. 32, no. 3, 2009, pp. 244-256.

Robbins, Trina, editor. The Complete Wimmen's Comix. Fantagraphics, 2016.

Robbins, Trina, and Catherine Yronwode. Women and the Comics. Eclipse Books, 1985.

Rohrman, Starr. "Personal interview." 22 March 2017.

Smith-Rosenberg, Carroll. Disorderly Conduct: Visions of Gender in Victorian America. Oxford University Press, 1986.

Spiegelman, Art. Lead Pipe Sunday. Lithograph on paper. The Billy Ireland Cartoon Library \& Museum Collection. Columbus, OH. 1990.

Theophano, Teresa. "GLBTQ Comic Strips and Cartoons." GLBTQ: An Encyclopedia of Gay, Lesbian, Bisexual, Transgender, and Queer Culture. 2005. http://www.glbtqarchive.com/arts/ comic_strips_cartoons_A.pdf. Accessed 21 February 2017.

Winn, Marcia. “A Star Reporter Writes about a Starr Reporter.” Chicago Tribune, 14 January, 1945, p. 1. 